\title{
A new spider wasp from Western Australia, with a description of the first known male of the genus Eremocurgus (Hymenoptera: Pompilidae)
}

\author{
L. Krogmann ${ }^{1.2}$, M.C. Day ${ }^{3}$ and A.D. Austin ${ }^{1}$ \\ 'Australian Centre for Evolutionary Biology and Biodiversity, The University of Adelaide, \\ South Australia 5005, Australia \\ ¿State Museum of Natural History Stuttgart, Rosenstein 1, Stuttgart, D-70191 Germany (present address). \\ Email: krogmann.smns@naturkundemuseum-bw.de \\ National Museum Cardiff, Cathays Park, Cardiff, CF10 3NP, Wales, United Kingdom.
}

\begin{abstract}
Eremocuryzs limali sp. nov. is described from Western Australia. The female of this new species is brachypterous, a unique feature within Eremocurgus Haupt and rare within the Australian pompilid fauna. The fullywinged male is the first recorded for the genus. The diversity of Eromocurghis, its distribution and brachyptery among the Pompilidae are discussed.
\end{abstract}

\section{INTRODUCTION}

The Australian pompilid fauna is particularly diverse (Austin ot al. 2004) and displays a high level of endemism. However, although the first Pompilidae for the continent were described by Fabricius in 1775, the group is generally poorly known for Australia, and it is likely that significantly less than half the fauna has been described. Further, the group is taxonomically difficult because of the morphological conservatism among numerous genera, in addition to the often extreme sexual dimorphism and complex mimicry associations seen in many species (e.g. Evans 1968, 1982; Harris 1987; Day 1988). Elliott (2007) lists 258 pompilid species for the Australian region of which the majority have been described from the eastern parts of the continent. Despite comprising onethird of the continent's landmass, Western Australian Pompilidae have been little studied. Only $18 \%$ of all pompilid species (47 of 258 species) are described from Western Australia, while for the subfamily Pepsinae only $12 \%$ (11 of 91 species) have type localities in that region (data from Elliott 2007). Of the four recognised subfamilies (Pitts et al. 2006; Elliott 2007), the Pepsinae comprise the least known Australian genera, many of which are monotypic or contain only few species. Several of these genera have not been revised since their original description (Elliott 2007), as is the case for Eremocurgus Haupt which is currently known from two species from south-eastern Australia.

Here we describe a remarkable new species of the Australian endemic genus Eremocurgus from Western Australia, and thus record the first brachypterous female and the first male of the genus. At the same time, we present an overview of the diversity and distribution of the genus, and discuss the occurrence of brachyptery within the Australian Pompilidae.

\section{TERMINOLOGY AND METHODS}

Terms for morphological structures follow Day (1988) and Goulet and Huber (1993). Specimens were borrowed from and/or are deposited in the following collections (acronyms used throughout the text): Australian Museum, Sydney, Australia (AM); Australian National Insect Collection, CSIRO, Canberra, Australia (ANIC); California Academy of Sciences, San Fransisco, U.S.A. (CAS); The Natural History Museum, London, England (NHM); Museum Victoria, Melbourne, Australia (NMV); State Museum of Natural History Stuttgart, Germany (SMNS); Western Australian Museum, Perth, Australia (WAM); Waite Insect and Nematode Collection, University of Adelaide, Australia (WINC).

Images of the specimens were taken with a Leica DXM 1200 digital camera attached to a Leica MZ 16 APO microscope and processed using Auto-Montage (Syncroscopy) software

\section{SYSTEMATICS}

Family Pompilidae Latreille 1805

Eremocurgus Haupt 1937

Eremocurys Haupt 1937: 127, 133

Type species

Priocne'mis ephippiata Smith 1868 , by original designation. 


\section{Diagnosis}

Both sexes with fore-wings spotted or bifasciate, propodeum with relatively weakly defined declivity. Female with tooth-like scales (=Haupt's 'Schuppendornen') developed at bases of hind tibial spines. Male subgenital plate medially with distinct posteriorly-directed spine.

\section{Remarks}

In his work on Australian Pepsinae, Haupt (1937) described nine new genera (including six genera with males unknown to him) in which he accommodated just 18 species. Two of these species were placed by Haupt (1937) in Eremocurgus: E. ephippiatus (Smith 1868) and E. pictipennis (Smith, 1855). In recent years it has become apparent that Eremocurgus and other pepsine genera putatively related to it require extensive reinterpretation to recognise more natural groups, and this will likely involve synonymy of some genera and an expansion of the limits of Eremocurgus. Such a study is currently being undertaken by the authors as part of a larger generic revision of Australian Pomplilidae, and the description of the present species makes a small contribution in this respect. The diagnosis of Eremocurgus sensu Haupt presented above has been modified to include both the brachypterous female and first recorded male for E. linnaei.

Based on this species, Eremocurgus exhibit a striking level of sexual dimorphism, which led to the males of E. linnaei remaining unrecognised in the ANIC collection. Our postulated sex association is supported by the close geographic occurrence of males and females.

Eremocurgus linnaei is only known from Western Australia, while E. ephippiatus has a broad distribution covering Victoria, South Australia and Western Australia (collection data), whereas E. pictipennis is apparently restricted to Victoria.

\section{Eremocurgus linnaei Krogmann, \\ Day and Austin, sp. nov.}

Figures 1a-j

\section{Material examined}

Holotype

Australia: Western Australia: $q$, Stirling Range National Park, S. face of Pyungoorup Peak, $330 \mathrm{~m}$, 34'22'17"S, 118 $19^{\prime} 20^{\prime \prime}$ E, 27 April-4 September 1996, wet pitfall traps ex spirit collection, M.S. Harvey, J.M. Waldock, B.Y. Main (WAM Entomology Reg. No. 68761).

\section{Paratypes}

Australia: Western Australia: $1 q$, same collection data as holotype (WAM Entomology Reg. No. 68760); 6 \%, same data as holotype, but:

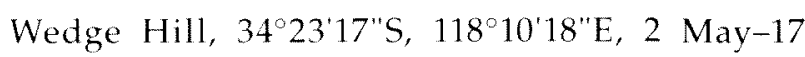
Dec 1996 (1 specimen SMNS, 5 specimens WAM Entomology Reg. No. 68633-68637); 1 $\{$, same data as holotype, but: Mt Magog, 34 23 59"S, 117 56 35"E, 25 April-3 September 1996 (NHM); 1 , same collection data as holotype,

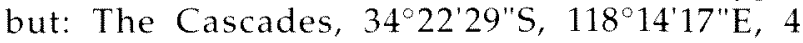
September-17 December 1996 (WAM Entomology Reg. No. 69771); 19 \&, same data as holotype, but: Toolbrunup Peak track, 34 23'32"S, 118 03'32"E, 23 April-3 September 1996, J.M. Waldock, B.Y.Main (WAM Entomology Reg. No. 69744-69762); 3 q, same data as holotype, but: Talyuberlup picnic

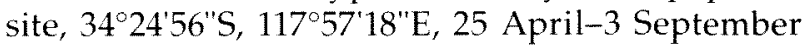
1996, J.M. Waldock, B.Y. Main (1 specimen SMNS, 2 specimens WINC); 3 q, same data as holotype, but: Porongurup National Park, south end of Millinup Pass, 34\%41'43'S, 117 53'51'E, 28 April-2 September 1996 (1 specimen ANIC, 2 specimens WAM Entomology Reg. no. 68631-68632); 1 q, Porongurup National Park, Yate Flats, malaise, 13 November 1987, M.E. Irwin, E.I. Schlinger (CAS); 1 \&, Stirling Range National Park, Bluff Knoll at Cascade Track, malaise, 17-20 November 1987, M.E. Irwin, E.I. Schlinger (CAS); $20,7 \mathrm{~km} \mathrm{~N}$. of Kent River Bridge, 34 54'S, 117 02'E, 19 April 1983, E.S. Nielsen, E.D. Edwards (ANIC).

\section{Diagnosis}

The female of $E$. linnaei differs from the previously described species of Eremocurgus by the following characters: head with red-golden pubescence (Figure 1e), fore- and hind-wing brachypterous (Figure 1a, c), propodeum elongate, with transverse striae, that are medially weakly indicated (Figure 1f), toothed scales on hind tibia only weakly developed (Figure $1 \mathrm{~g}$ ). The male is the first described for the genus and characterized by the following diagnostic features: head black, face with orange area extending laterodorsally from level of toruli (Figure 1h). Male with metapostnotum well developed, reaching three quarters of the median length of the metascutellum (Figure 1i).

\section{Description}

Female (Figure 1a, c,e-g)

Body length: $13.0-17.1 \mathrm{~mm}$, head plus mesosoma: 6.5-8.3 mm. Colour: Body and legs brownishpurple. Antennae brown. Conspicuous redgolden pubescence present on head, tibiae, tarsi and dorsal surfaces of meso- and metasoma. Two patches of silvery pubescence present on anterolateral portions of metasomal tergites 2 and 3.

Head (Figure 1e): Inner eye margin only very slightly incised, eye 1.9-2.1 times as long as wide. Clypeus $3.1-3.3$ times as long as wide and as 


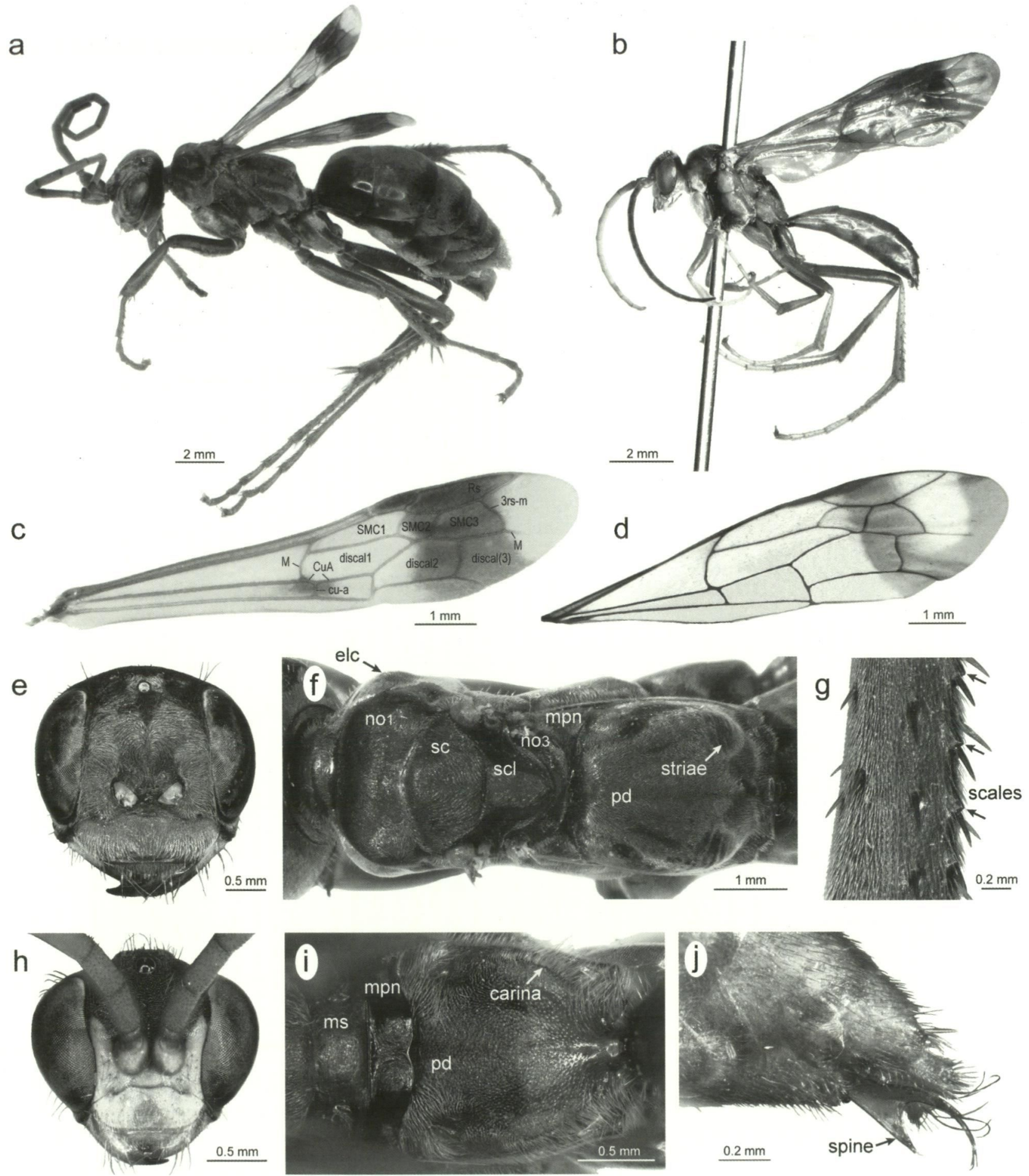

Figure 1 Eremocurgus linnaei sp. nov., paratypes - a, habitus female, lateral view; b, habitus male, lateral view; c, forewing female; $\mathrm{d}$, forewing male; $\mathrm{e}$, head female, frontal view; $\mathrm{f}$, mesosoma female, dorsal view; $\mathrm{g}$, hind tibia female, dorsolateral view; $h$, head male, frontal view; i, posterior mesosoma male, dorsal view; $j$, metasoma with subgenital plate male, lateral view. Abbreviations: elc=extended lateral corner; no1=pronotum; no3=metanotum; $\mathrm{mpn}=$ metapostnotum; $\mathrm{ms}=$ metascutellum; $\mathrm{pd}=$ propodeum; $\mathrm{sc}=$ mesoscutum; $\mathrm{scl}=$ mesoscutellum; SMC=submarginal cell. 
wide as distance between bottoms of orbits. First flagellomere $3.7-4.2$ times as long as wide and 1.1-1.2 times as long as second. Ocello/oculardistance 1.7-1.8 times as wide as interocellulardistance, ocelli not enlarged.

Mesosoma (Figure 1f): Pronotum transversely divided by distinct groove (=streptaulus), anteriorly with extended lateral corners. Mesonotum narrower than pronotum, paraspidal sulcus present, reaching half the length of mesoscutum. Propodeum elongate, nearly as long as combined length of pro- and mesonotum. Propodeal surface with transverse striae covering anterior half of declivity. Most striae only laterally distinct

Wings: Brachypterous, forewing $6.3-7.8 \mathrm{~mm}$, hindwing 5.0-6.1 mm. Forewing (Figure 1a, c) orange with black infuscation around crossvein cu-a, and black band covering marginal cell and running to inner wing margin, covering third and most of second submarginal cell, great proportions of discal2, discal (3) and subdiscal (2). Vein M distad of crossvein 3rs-m very short, terminating well before wing margin. Third submarginal cell enlarged, approximately twice the size of second. Crossvein cu-a relatively strongly postfurcal of $M$ on $\mathrm{CuA}$. Hindwing with full venation, subdiscal cell proximally with unpigmented vein.

Legs: Hind femur 5.9-6.3 times as long as wide; inner hind tibial spur 0.4 times times as long as basitarsus. Hind tibia with weakly developed toothed scales (Figure 1g). Tarsal plantulae present.

\section{Male (Figure $1 b, d, h-j)$}

Body length: $9.8-10.6 \mathrm{~mm}$, head plus mesosoma: 4.6-5.2 mm. Colour: Head bicoloured, clypeus and face below toruli light orange, coloured area also extends laterodorsally from toruli, rest of head black. Antennae and legs orange. Mesosoma bicoloured, mainly dark orange, with the following areas black: anterior portion of propleura, ventral mesepisternum and small anterior portion of mesepisternum, adjacent to pronotum, mesoscutum, lateral panels of metanotum, metapostnotum and anterior portion of propodeum between and anterior to propodeal spiracles. Metasoma orange with anterior portion of petiole black.

Head (Figure 1h): Inner eye margin convergent, eye 1.9-2.1 times as long as wide. Clypeus 2.6 times as long as wide and as wide as distance between bottoms of orbits. First flagellomere 2.02.1 times as long as wide and $0.8-0.9$ times as long as second. Ocello/ocular-distance $0.9-1.0$ times as wide as interocellular-distance, median ocellus slightly enlarged.
Mesosoma: Pronotum short, with long pubescence. Mesonotum with fine punctuation, parapsidal sulcus present, reaching close to anterior mesoscutal margin, notaulus absent Metapost-notum well developed, posterior margin only slightly incised medially (Figure 1i). Median length of metapostnotum reaching three quarters of the median length of the metascutellum (Figure 1i). Propodeal surface without transverse striae, but two strong dorsolateral carinae reaching from posterior margin to about half the length of propodeum (Figure 1i)

Wings: Fully developed. Forewing (Figure 1d) with less conspicuous black band originating from marginal cell and without black infuscation around crossvein cu-a. Black infuscation present along wing tip. Vein $M$ distad of crossvein 3rs-m longer than in female; third submarginal cell only slightly larger than second, with 3rs-m strongly bent towards Rs. Crossvein cu-a not strongly postfurcal of $\mathrm{M}$ on $\mathrm{CuA}$. Hindwing very similar to female, but subdiscal cell proximally with pigmented vein.

Legs: Hind femur 7.1 times as long as wide; inner hind tibial spur elongate, 0.7 times as long as basitarsus. Tarsal plantulae present.

Metasoma: Subgenital plate with distinct posteromedian spine (Figure 1j).

\section{Etymology}

The new species is described and named in honour of Carl von Linné and published 250 years after the tenth edition of his Systema Naturae.

\section{Remarks}

\section{Brachyptery in Australian Hymenoptera}

Brachyptery is a rare phenomen within the world Pompilidae (Goulet and Huber 1993). In Australia wing-reduced pompilids have only been described in the Iridomimus violaceus group (Evans 1970), where both sexes have strongly reduced, strap-like wings and greatly resemble ants. Eremocurgus linnaei is the first described pompilid from Australia, in which wing reduction only occurs in the female. Interestingly, we have found this phenomenon also in two undescribed Australian species from the genera Epipompilus Kohl and Sphictostethus Kohl (Krogmann, Day and Austin, unpublished data). The Australian Hymenoptera fauna includes a number of families, in which brachypterous species occur more frequently than in other parts of the world. These include doryctine Braconidae (75\% of all known brachypterous species; Iqbal et al. 2003) and Rhopalosomatidae (70\% of all known brachypterous species; Krogmann et al. in prep.). 


\section{ACKNOWLEDGEMENTS}

This work was supported by a Feodor Lynen Fellowship of the Alexander von Humboldt Foundation to LK and an Australian Biological Resources Study Grant to ADA. This study would not have been possible without the efforts of Julianne Waldock and Mark Harvey (WAM) who collected all of the pitfall material. We wish to thank the following people for kindly providing access to their pompilid collections and for processing the loans: Terry Houston and Brian Hanich (WAM), John LaSalle and Nicole Fisher (CSIRO Entomology, ANIC), Dave Britton, Michael Elliott, Derek Smith (AM), and Ken Walker (NMV). An earlier version of this manuscript was improved by insightful comments of Ken Walker and an anonymous referee.

\section{REFERENCES}

Austin, A.D., Yeates, D.K, Cassis, G., Fletcher, M.J., La Salle, J., Lawrence, J.F., McQuillan, P.B., Mound, L.A., Bickel, D.J., Gullan, P.J., Hales, D.F. and Taylor, G.S. (2004). Insects 'Down Under'- Diversity, endemism and evolution of the Australian insect fauna: examples from select orders. Australian foumal of Entomology 43: 216-234

Day, M.C. (1988). Spider wasps. Hymenoptera: Pompilidae. Handbooks for the Identification of British Insects Vol. VI, Part 4. Royal Entomological Society of London: London.

Elliott, M.G. (2007). Annotated catalogue of the Pompilidae (Hymenoptera) of Australia. Zootaxa 1428: $1-83$.

Evans, H.E. (1968). Studies on neotropical Pompilidae (Hymenoptera) IV. Examples of dual sex-limited mimicry in Chirodamms. Psyche 75: 1-22.

Evans, H.E. (1970). A new genus of ant-mimicking spider wasps from Australia (Hymenoptera, Pompilidae). Psyche 77: 303-307.
Evans, H.E. (1982). The "collaris" complex of Australian mimetic Pompilidae (Hymenoptera). Pacific Imsects 24: $151-155$.

Fabricius, J.C. (1775) Systema Entomologicat, Sistens insectoram classes, ordines, genera, species, adjectis stmontumis, loci, decriptionibus, obsereationibus. Korte: Flensburg and Leipzig, Germany.

Goulet, H. and Huber, J.T. (1993). Hymenoptern of the world: An identification guide to families. Agriculture Canada, Research Branch: Ottawa, Canada.

Haupt, H. (1937). Beitrag zur Kenntnis der Psammochariden-Fauna Australiens (Spinnenfangende Wegwespen) Subf. Claveliinae Hpt. Trib. Calicurgini nov. Zeitschrift fïr Naturwissenschaft 91: 121-136.

Harris, A.C. (1987). Famn of New Zenland 12. Pompilidae. DSIR: Auckland, New Zealand.

Iqbal, M., Austin, A.D. and Belokobylskij, S.A. (2003) Diversity and biogeography of reduced-winged doryctine wasps (Hymenoptera: Braconidae) in Australasia. Records of the South Australian Museum 7 : 243-247.

Pitts, J.P., Wasbauer, M.S and Von Dohlen, C.D. (2006). Preliminary morphological analysis of relationships between the spider wasp subfamilies (Hymenoptera: Pompilidae): revisiting an old problem. Zoologica Scripta 35: 1-22.

Smith, F. (1855). Catalogue of humenopterous insects in the collection of the British Museum. Part 3. Mutillidac and Pompilidae. British Museum of Natural History: London.

Smith, F. (1868). Descriptions of aculeate Hymenoptera from Australia. Transactions of the Royal Entomological Society of London 1868: 231-258.

Manuscript received 7 March 2008; accepted 22 May 2008. 